\title{
Survei Kesehatan Telinga Masyarakat di Desa Tinoor 2
}

\author{
${ }^{1}$ Kevin Liang \\ ${ }^{2}$ Moudi Mona \\ ${ }^{2}$ R. E. C. Tumbel
}

\author{
${ }^{1}$ Program Studi Pendidikan Dokter Fakultas Kedokteran Universitas Sam Ratulangi Manado \\ ${ }^{2}$ Bagian Telinga Hidung Tenggorok-Bedah Kepala dan Leher Fakultas Kedokteran \\ Universitas Sam Ratulangi Manado \\ Email: kevinarsastha@gmail.com
}

\begin{abstract}
Ear health plays an important role in the quality of life. Unfortunately, ear health is often overlooked although its cleanliness has implication to hearing acuity. Disorders of ear include diseases of the outer ear, middle ear, and inner ear as well as hearing loss. This study was aimed to obtain the ear health status of villagers at Tinoor 2 . This was a descriptive study. There were 40 villagers in this study consisted of 12 males and 28 females. The results showed that the ear health status of 6 male villagers (50\%) and 12 female villagers (42.85\%) was categorized as good. Based on age category, good ear health status was more common among adult age, and based on job, good ear health status was more common among college students and teachers. Conclusion: At Tinoor 2, good health status was more common among males, adult age, and those who were students or teachers/official servants.
\end{abstract}

Keywords: ear health

\begin{abstract}
Abstrak: Kesehatan telinga merupakan salah satu tolak ukur kualitas hidup seseorang tetapi seringkali kurang mendapat perhatian padahal kebersihan telinga mempunyai implikasi terhadap ketajaman pendengaran. Gangguan kesehatan telinga meliputi telinga bagian luar, bagian tengah, dan bagian dalam, serta gangguan pendengaran. Penelitian ini bertujuan untuk mendapatkan gambaran kesehatan telinga pada masyarakat Desa Tinoor 2. Jenis penelitian ialah desktriptif. Sebanyak 40 orang masyarakat Desa Tinoor 2 yang dilakukan pemeriksaan telinga, terdiri dari 12 laki-laki dan 28 perempuan. Hasil penelitian menunjukkan bahwa status kesehatan telinga yang baik didapatkan pada 6 orang laki-laki (50\%) dan 12 orang perempuan $(42,85 \%)$. Berdasarkan kategori usia, status kesehatan telinga yang baik lebih sering pada usia dewasa sedangkan berdasarkan pekerjaan, lebih sering pada mahasiswa dan guru/PNS. Simpulan: Di Desa Tinoor 2, kesehatan telinga yang baik lebih sering didapatkan pada jenis kelamin laki-laki, dewasa, dan yang bekerja sebagai siswa atau guru/PNS.
\end{abstract}

Kata kunci: kesehatan telinga

Kesehatan telinga adalah salah satu tolak ukur kualitas hidup seseorang. Sayangnya kesehatan telinga seringkali kurang diperhatikan, padahal kebersihan telinga mempunyai implikasi terhadap ketajaman pendengaran. Hal ini dapat terjadi bila substansi benda asing terkumpul dalam kanal telinga luar sehingga mengganggu konduksi suara. Oleh karena itu, kebersihan dan kesehatan telinga perlu dipelihara agar tidak mengganggu fungsi dari telinga itu sendiri. ${ }^{1}$

Kurangnya perhatian terhadap kebersihan telinga dapat menyebabkan berbagai gangguan yang meliputi penyakit gangguan telinga bagian luar, bagian tengah, dan bagian dalam, serta gangguan pendengaran. $^{2}$

Berdasarkan hasil Survei Nasional Kesehatan Indera Penglihatan dan Pende- 
ngaran yang dilaksanakan di 7 provinsi, prevalensi ketulian di Indonesia ialah 0,4\% dan gangguan pendengaran $16,8 \%$, dengan penyebab utama gangguan pendengaran ialah: infeksi telinga tengah $(3,1 \%)$, presbikusis $(2,6 \%)$, tuli akibat obat ototoksik $(0,3 \%)$, tuli sejak lahir/kongenital $(0,1 \%)$, dan tuli akibat pemaparan bising. ${ }^{3}$

Kurangnya kebersihan telinga dapat menyebabkan penyakit otitis media yang merupakan salah satu penyebab utama gangguan pendengaran dan ketulian. Pendengaran berkurang dapat menyebabkan ketidakmampuan berkomunikasi dan mengikuti pelajaran formal di sekolah umum. Survei epidemiologi di 7 propinsi Indonesia, melaporkan bahwa dari 19.375 responden yang diperiksa ternyata $18,5 \%$ mengalami gangguan kesehatan telinga dan pendengaran. Penderita otitis media supuratif kronik (OMSK) merupakan 25\% dari penderita yang datang berobat di poliklinik THT rumah sakit di Indonesia dengan prevalensi sebesar 3,8\%. Penelitian yang dilakukan di sekolah dasar di Makassar mendapatkan dari 5052 murid yang diperiksa didapatkan otitis media sebanyak 2,5\%. Tidak terdapat perbedaan usia dan jenis kelamin pada prevalensi otitis media, namun ditemukan lebih tinggi secara bermakna pada murid sekolah yang tinggal di pinggiran kota, berasal dari orang tua dengan tingkat sosial-ekonomi yang rendah dan berpendidikan rendah. Otitis media juga lebih tinggi secara bermakna pada murid yang tinggal di keluarga dengan jumlah anggota keluarga kurang atau sama dengan lima orang dan pada murid yang tidak bersih. ${ }^{4}$

Selain itu, risiko gangguan pada telinga juga dapat disebabkan oleh lingkungan tempat tinggal serta aktivitasnya. Penduduk dataran tinggi yang kesehariannya beraktivitas di dataran rendah mengalami perubahan tekanan udara dalam setiap perjalanannya dengan faktor risiko yaitu dari barotrauma.

\section{METODE PENELITIAN}

Jenis penelitian ini ialah deskriptif. Penelitian dilakukan pada tanggal 15
November 2014. Populasi penelitian ialah sebanyak 40 orang penduduk Desa Tinoor 2 .

Pada penelitian ini dilakukan pemeriksaan langsung pada telinga responden. Data hasil pemeriksaan diisi pada tabel pemeriksaan THT yang telah disediakan dan diolah dengan menggunakan Microsoft Word serta Microsoft Excel.

\section{HASIL PENELITIAN}

Gambaran kesehatan telinga penduduk Desa Tinoor 2 dengan jumlah 40 responden dideskripsikan berdasarkan jenis kelamin, kategori usia, dan pekerjaan. Dari hasil penelitian ditemukan 3 gangguan/penyakit telinga yang didiagnosis berdasarkan hasil pemeriksaan telinga, yaitu: serumen, otitis eksterna, dan otitis media.

Tabel 1 menampilkan gambaran kesehatan telinga penduduk desa Tinoor 2 berdasarkan jenis kelamin.

Tabel 1. Gambaran kesehatan telinga berdasarkan jenis kelamin

\begin{tabular}{ccc}
\hline $\begin{array}{c}\text { Status kesehatan } \\
\text { telinga }\end{array}$ & Laki-laki & Perempuan \\
\hline Normal & 6 & 12 \\
Serumen & 4 & 11 \\
Otitis Eksterna & 1 & 3 \\
Otitis Media & 1 & 2 \\
Total & 12 & 28 \\
\hline
\end{tabular}

Tabel 2 memperlihatkan gambaran kesehatan telinga berdasarkan usia. Kategori usia yang digunakan ialah sesuai dengan klasifikasi Departemen Kesehatan Indonesia pada tahun 2009. Untuk usia 1-5 tahun dikategorikan sebagai balita; 6-11 tahun anak; 12-16 tahun remaja awal; 1725 tahun remaja akhir; 26-35 dewasa awal; 36-45 dewasa akhir; 46-55 tahun lansia awal; 56-65 tahun lansia akhir; dan >65 tahun dikategorikan sebagai manula. ${ }^{5}$

Tabel 3 menunjukkan bahwa berdasarkan pekerjaan didapatkan 18 orang siswa, 3 orang mahasiswa, 3 orang guru/PNS, 5 orang petani, 8 orang IRT, dan 3 responden yang tidak diketahui pekerjaannya 
Liang, Mona, Tumbel: Survei kesehatan telinga masyarakat di ...

Tabel 2. Gambaran kesehatan telinga berdasarkan kategori usia

\begin{tabular}{lcccc}
\hline & Normal & Serumen & $\begin{array}{c}\text { Otitis } \\
\text { eksterna }\end{array}$ & $\begin{array}{c}\text { Otitis } \\
\text { media }\end{array}$ \\
\hline Balita & 0 & 1 & 0 & 0 \\
Anak & 5 & 10 & 0 & 1 \\
Remaja & 3 & 0 & 2 & 0 \\
Dewasa & 5 & 1 & 1 & 0 \\
Lansia & 4 & 2 & 0 & 0 \\
Manula & 1 & 1 & 1 & 2 \\
Total & 18 & 15 & 4 & 3 \\
\hline
\end{tabular}

Tabel 3. Gambaran kesehatan telinga berdasarkan pekerjaan

\begin{tabular}{lcccc}
\hline & Normal & Serumen & $\begin{array}{c}\text { Otitis } \\
\text { eksterna }\end{array}$ & $\begin{array}{c}\text { Otitis } \\
\text { media }\end{array}$ \\
\hline Siswa & 5 & 10 & 2 & 1 \\
Mahasiswa & 3 & 0 & 0 & 0 \\
Guru/PNS & 3 & 0 & 0 & 0 \\
Tani & 1 & 2 & 1 & 1 \\
IRT & 4 & 2 & 1 & 1 \\
Lainnya & 2 & 1 & 0 & 0 \\
Total & 16 & 15 & 4 & 3 \\
\hline
\end{tabular}

\section{BAHASAN}

Pada penelitian ini didapatkan 40 responden yang terdiri dari 12 orang lakilaki $(30 \%)$ dan 28 orang perempuan (70\%). Berdasarkan kategori usia didapatkan yang terbanyak ialah siswa (45\%) dan anak $(40 \%)$. Untuk jenis pekerjaan terdiri dari siswa $(45 \%)$, mahasiswa $(7,5 \%)$,guru/PNS $(7,5 \%)$, tani $(12,5 \%)$, IRT $(20 \%)$, dan yang tidak diketahui $(7,5 \%)$.

Berdasarkan jenis kelamin, ditemukan bahwa kesehatan telinga pada laki-laki lebih baik daripada perempuan. Hasil penelitian ini menyatakan bahwa 6 orang lakilaki $(50 \%)$ dan 12 orang perempuan $(42,85 \%)$ tidak mengalami gangguan apapun pada telinga (kesehatan telinga baik). Serumen didapatkan pada 4 orang laki-laki $(33,33 \%)$ dan 11 orang perempuan $(39,28 \%)$. Terdapat 1 orang laki-laki $(9,09 \%)$ dan 3 orang perempuan $(10,71 \%)$ dengan otitis eksterna. Terdapat 1 orang laki-laki $(9,09 \%)$ dan 2 orang perempuan $(7,14 \%)$ dengan otitis media.

Berdasarkan kategori usia, tidak didapatkan serumen pada 5 orang remaja.
Serumen didapatkan pada satu-satunya balita yang diperiksa, 10 orang anak $(62,5 \%), 1$ orang dewasa $(14,28 \%), 2$ orang lansia $(33,33 \%)$, dan 1 orang manula (20\%). Terdapat 2 orang remaja (40\%), 1 orang dewasa $(14,28 \%)$, dan 1 orang manula (20\%) yang menderita otitis eksterna. Didapatkan pula 1 orang anak $(6,25 \%)$ dan 2 orang manula $(50 \%)$ dengan otitis media.

Status kesehatan telinga terbaik didapatkan pada kategori usia dewasa dengan 5 orang $(71,42 \%)$ tidak memiliki kelainan apapun pada telinga, diikuti oleh lansia $(66,66 \%)$, remaja $(60 \%)$, anak $(31,25 \%)$, manula $(20 \%)$, dan balita $(0 \%)$. Dari hasil tersebut, dapat dilihat bahwa kelompok usia balita, anak, dan manula memiliki status kesehatan telinga yang terburuk. Hal tersebut sesuai dengan teoriteori dan hasil penelitian sebelumnya yang menyatakan bahwa gangguan telinga sering terjadi pada kelompok anak kecil dan usia pra sekolah, yaitu sebesar 3\%-4\% anak. Status kesehatan telinga kelompok usia manula menurun karena proses penuaan. 
Perubahan pada telinga luar sehubungan dengan proses penuaan ialah elastisitas kulit telinga berkurang. Daerah lobus yang merupakan satu-satunya bagian yang tidak disokong oleh kartilago mengalami pengeriputan, aurikel tampak lebih besar dan tragus sering ditutupi oleh rumbairumbai rambut yang kasar. Saluran auditorius menjadi dangkal akibat lipatan ke dalam, pada dinding silia menjadi lebih kaku dan kasar. juga produksi serumen agak berkurang dan cenderung menjadi lebih kering. ${ }^{6,7}$

Berdasarkan pekerjaan, 5 orang siswa (27\%), 3 orang mahasiswa (100\%), 3 orang guru/PNS $(100 \%), 1$ orang tani $(20 \%), 4$ orang IRT $(50 \%)$, dan 2 orang $(66,66 \%)$ yang tidak diketahui pekerjaannya tidak mengalami gangguan apapun pada telinga. Didapatkan serumen pada 10 orang siswa (55,55\%), 2 orang tani (40\%), 2 orang IRT (25\%), dan 1 orang lainnya $(33,33 \%)$. Tidak didapatkan serumen pada mahasiswa dan guru/PNS. Terdapat 2 orang siswa $(11,11 \%), 1$ orang tani $(20 \%)$, dan 1 orang IRT $(12,5 \%)$ yang menderita otitis eksterna. Terdapat 1 orang siswa $(5,55 \%)$, 1 orang tani (20\%), dan 1 orang IRT $(12,5 \%)$ dengan otitis media.

\section{SIMPULAN}

Dari hasil penelitian ini dapat disim- pulkan bahwa di Desa Tinoor 2, kesehatan telinga yang baik lebih sering didapatkan pada jenis kelamin laki-laki, dewasa, dan yang bekerja sebagai siswa atau guru/PNS.

\section{DAFTAR PUSTAKA}

1. Andarmoyo S. Personal Hygiene: Konsep, Proses dan Aplikasi dalam Praktik Keperawatan. Yogyakarta: Graha Ilmu, 2012.

2. Higler AB. Buku ajar penyakit THT (6th ed). Jakarta: EGC, 2007.

3. Depkes RI. Workshop Pengembangan Program Kesehatan Indera Pendengaran. Direktorat Bina Upaya Kesehatan Kementerian Kesehatan RI, 2012.

4. Muhammad F. Otitis media prevalance in primary school children in Makasar. Fakultas Kedokteran Universitas Hasanuddin. 2010. [cited 2014 Nov 23]. Available from : http://med.unhas.ac.id.

5. Depkes RI. Profil Kesehatan Indonesia. Jakarta: Departemen Republik Indonesia. 2009. [cited 2014 Dec 11]. Available from: http://depkes.go.id.

6. Probst R, Grevers G, Iro H. Basic Otorhinolaryngology. A Step-by-Step Learning Guide. Thieme, 2006.

7. Maryam S. Mengenai Usia Lanjut dan Perawatannya. Jakarta: Salemba Medika, 2008.

8. Adams GL, Lawrence R. Buku Ajar Penyakit THT (6th ed). Jakarta: EGC, 1997. 